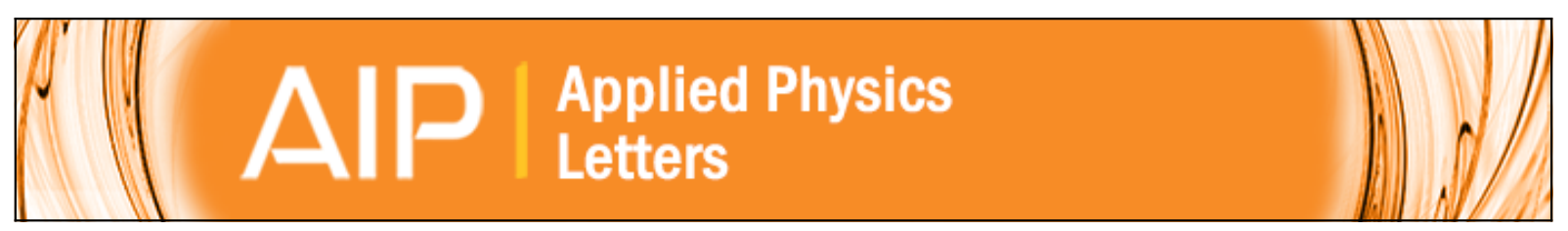

\title{
Lattice positions of Sn in Cu2ZnSnS4 nanoparticles and thin films studied by synchrotron X-ray absorption near edge structure analysis
}

E. Zillner, A. Paul, J. Jutimoosik, S. Chandarak, T. Monnor, S. Rujirawat, R. Yimnirun, X. Z. Lin, A. Ennaoui, Th. Dittrich, and M. Lux-Steiner

Citation: Applied Physics Letters 102, 221908 (2013); doi: 10.1063/1.4809824

View online: http://dx.doi.org/10.1063/1.4809824

View Table of Contents: http://scitation.aip.org/content/aip/journal/apl/102/22?ver=pdfcov

Published by the AIP Publishing

\section{Articles you may be interested in}

Investigation of combinatorial coevaporated thin film Cu2ZnSnS4 (II): Beneficial cation arrangement in Cu-rich growth

J. Appl. Phys. 115, 173503 (2014); 10.1063/1.4871665

Strain tuning of native defect populations: The case of Cu2ZnSn(S,Se)4

APL Mat. 2, 012110 (2014); 10.1063/1.4863076

Model of native point defect equilibrium in Cu2ZnSnS4 and application to one-zone annealing

J. Appl. Phys. 114, 124501 (2013); 10.1063/1.4819206

Determination of secondary phases in kesterite Cu2ZnSnS4 thin films by $\mathrm{x}$-ray absorption near edge structure analysis

Appl. Phys. Lett. 99, 262105 (2011); 10.1063/1.3671994

Analysis of lattice site occupancy in kesterite structure of Cu2ZnSnS4 films using synchrotron radiation x-ray diffraction

J. Appl. Phys. 110, 074511 (2011); 10.1063/1.3642993

\section{A|P| $\begin{aligned} & \text { Journal of } \\ & \text { Applied Physics }\end{aligned}$}

Journal of Applied Physics is pleased to

announce André Anders as its new Editor-in-Chief 


\title{
Lattice positions of $\mathrm{Sn}$ in $\mathrm{Cu}_{2} \mathrm{ZnSnS}_{4}$ nanoparticles and thin films studied by synchrotron $X$-ray absorption near edge structure analysis
}

\author{
E. Zillner, ${ }^{1, a)}$ A. Paul, ${ }^{2}$ J. Jutimoosik, ${ }^{3}$ S. Chandarak, ${ }^{3}$ T. Monnor, $^{3}$ S. Rujirawat, ${ }^{3}$ \\ R. Yimnirun, ${ }^{3}$ X. Z. Lin, ${ }^{1}$ A. Ennaoui, ${ }^{1}$ Th. Dittrich, ${ }^{1}$ and M. Lux-Steiner ${ }^{1}$ \\ ${ }^{1}$ Helmholtz-Zentrum Berlin für Materialien und Energie, Hahn-Meitner Platz 1, 14109 Berlin, Germany \\ ${ }^{2}$ Technische Universität München, Physik Department E21, James-Franck-Straße 1, 85748 Garching, \\ Germany \\ ${ }^{3}$ School of Physics, Institute of Science, Suranaree University of Technology, and NANOTEC-SUT Center \\ of Excellence on Advanced Functional Nanomaterials, Nakhon Ratchasima 30000, Thailand
}

(Received 11 March 2013; accepted 23 May 2013; published online 6 June 2013)

\begin{abstract}
Lattice positions of $\mathrm{Sn}$ in kesterite $\mathrm{Cu}_{2} \mathrm{ZnSnS}_{4}$ and $\mathrm{Cu}_{2} \mathrm{SnS}_{3}$ nanoparticles and thin films were investigated by XANES (x-ray absorption near edge structure) analysis at the $\mathrm{S}$ K-edge. XANES spectra were analyzed by comparison with simulations taking into account anti-site defects and vacancies. Annealing of $\mathrm{Cu}_{2} \mathrm{ZnSnS}_{4}$ nanoparticle thin films led to a decrease of $\mathrm{Sn}$ at its native and defect sites. The results show that XANES analysis at the $\mathrm{S}$ K-edge is a sensitive tool for the investigation of defect sites, being critical in kesterite thin film solar cells. (C) 2013 AIP Publishing LLC. [http://dx.doi.org/10.1063/1.4809824]
\end{abstract}

Kesterite type $\mathrm{Cu}_{2} \mathrm{ZnSnS}_{4}$ is a semiconductor with a band gap of about $1.5 \mathrm{eV}$ and a large absorption coefficient what makes this material very interesting for applications in thin film solar cells. ${ }^{1}$ Despite the fact that relatively high energy conversion efficiencies have been already reached for solar cells with kesterite type absorbers, ${ }^{2-6}$ little is known about the nature of defects in related quaternary compounds. There is generally a large probability for formation of defects such as anti-site defects and vacancies in quaternary compounds. Especially, variations of the occupation of lattice sites in kesterite type absorbers seem to be crucial for the performance of solar cells with related absorbers. For example, relatively high energy conversion efficiencies could be only achieved for $\mathrm{Cu}_{2} \mathrm{ZnSnS}_{4}$ solar cells within a quite narrow region of $\mathrm{Cu}$-poor and Zn-rich compositions. ${ }^{1,4,7-9}$ Further, annealing of thin films with kesterite type nanoparticles is very important for the formation of $\mathrm{Cu}_{2} \mathrm{ZnSnS}_{4}$ absorbers. Annealing changes the occupation of lattice sites and therefore the formation of defect sites in a $\mathrm{Cu}_{2} \mathrm{ZnSnS}_{4}$ crystallite. Guo et al., for example, observed a loss of Sn during annealing under Se vapor. ${ }^{6}$ Tin is multivalent and can be a trap, donor, or acceptor depending on the lattice position in $\mathrm{Cu}_{2} \mathrm{ZnSnS}_{4}$. Simulations predict different energies for the transition between $\mathrm{Sn}^{+\mathrm{II}}$ and $\mathrm{Sn}^{+\mathrm{IV}}$ depending on the lattice position and the parameter and model used. ${ }^{10,11} \mathrm{~A}$ transition within in the band gap would lead to a defect state in the semiconductor. ${ }^{10}$ Accorindg to Biswas et al., Sn forms a defect only on the intrinsic $\mathrm{Zn}$ position, ${ }^{10}$ whereas according to Walsh et al., Sn also forms a deep defect on the $\mathrm{Cu}$ position. ${ }^{11}$ A more detailed analysis of the behavior of $\mathrm{Sn}$ atoms in $\mathrm{Cu}_{2} \mathrm{ZnSnS}_{4}$ can be useful for getting a deeper understanding of defects in kesterite type absorbers and for improving the performance of thin film solar cells based on $\mathrm{Cu}_{2} \mathrm{ZnSnS}_{4}$.

$\mathrm{Cu}_{2} \mathrm{ZnSnS}_{4}$ crystallizes in a kesterite lattice ${ }^{12,13}$ (space group $\mathrm{I} \overline{4}, \mathrm{a}=5.428 \AA$; $\mathrm{c}=10.846 \AA$ ) as shown in Figure 1 . Sulfur atoms occupy the $8 \mathrm{~g}$ lattice positions. Copper atoms

a)elisabeth.zillner@helmholtz-berlin.de occupy the $2 \mathrm{c}$ and $2 \mathrm{a}$ lattice positions, whereas tin and zinc atoms occupy the $2 \mathrm{~b}$ and $2 \mathrm{~d}$ lattice positions, respectively. Attention has been paid to the $\mathrm{Cu}-\mathrm{Zn}$ anti-site defect when copper atoms occupy $2 \mathrm{~d}$ positions and zinc atoms occupy $2 \mathrm{c}$ positions (investigations by neutron diffraction ${ }^{14}$ and synchrotron x-ray diffraction ${ }^{15}$ ). XANES at the S K-edge has been applied to determine the volume fraction of $\mathrm{ZnS}$ in the $\mathrm{Cu}_{2} \mathrm{ZnSnS}_{4}$ layer which is dependent upon the $\mathrm{Sn} / \mathrm{Zn}$ ratio by fitting XANES spectra with a linear combination of reference spectra of pure $\mathrm{Cu}_{2} \mathrm{ZnSnS}_{4}$ and $\mathrm{ZnS}^{16}$

This work is aimed for the analysis of anti-site defects and vacancies of $\mathrm{Sn}$ in kesterite type $\mathrm{Cu}_{2} \mathrm{ZnSnS}_{4}$ by a method suitable for monitoring nanoparticles and thin film layers. The influence of defects in kesterite, which are potential traps, on the performance of kesterite solar cells has to be studied to reach high efficiencies.

In this work, XANES (x-ray absorption near edge structure) at the $\mathrm{S}$ K-edge has been applied as a relatively fast and reliable method to characterize these defects. The sulfur atom in kesterite $\mathrm{Cu}_{2} \mathrm{ZnSnS}_{4}$ occupies the $8 \mathrm{~g}$ position and is surrounded by $\mathrm{Cu}$ (2c and 2a), Sn (2b), and $\mathrm{Zn}(2 \mathrm{~d})$ atoms in the first shell (see Figure 1). XANES at the $\mathrm{S}$ K-edge is therefore sensitive to the $2 \mathrm{a}, 2 \mathrm{~b}, 2 \mathrm{c}$, and $2 \mathrm{~d}$ positions. As a remark, EXAFS (extended x-ray absorption fine structure) is also a well-known method for the analysis of neighbor atoms in lattice positions. However, XANES is a much faster method for measurements in the fluorescence mode which is required for the investigation of thin films.

The $\mathrm{Cu}_{2} \mathrm{ZnSnS}_{4}$ nanoparticles were prepared by two different routes. The first preparation route was via a colloidal synthesis, which relied on the reaction of $\mathrm{Cu}_{2} \mathrm{SnS}_{3}$ $(\mathrm{d}=10 \mathrm{~nm})$ and $\mathrm{ZnS}(\mathrm{d}=5 \mathrm{~nm})$ nanoparticles. This resulted in kesterite $\mathrm{Cu}_{2} \mathrm{ZnSnS}_{4}$ nanoparticles with a diameter of $14 \pm 3 \mathrm{~nm}$. The $\mathrm{Cu}_{2} \mathrm{SnS}_{3}$ nanoparticles crystallized in the stannite structure. We employed a second preparation route of $\mathrm{Cu}_{2} \mathrm{ZnSnS}_{4}$ nanoparticles synthesis which is a one pot technique. The synthesis works by a high-temperature arrested precipitation in the coordinating solvent after 


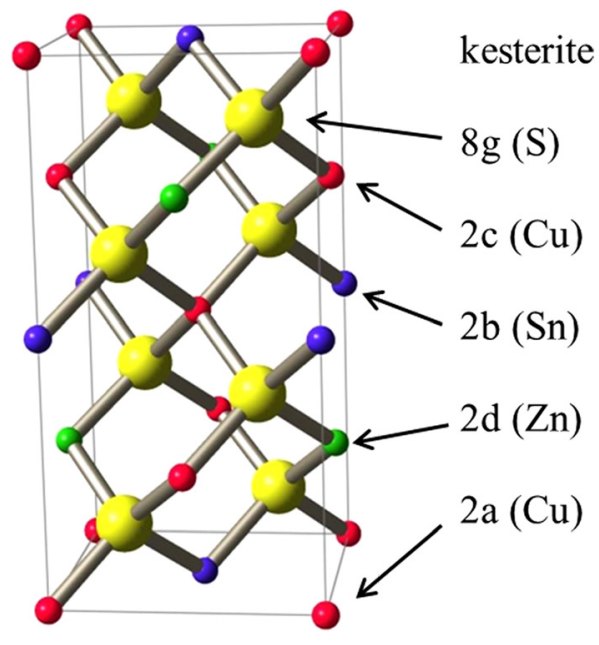

FIG. 1. Kesterite structure of $\mathrm{Cu}_{2} \mathrm{ZnSnS}_{4}$ with nomenclature and occupation of lattice sites.

Steinhagen, but at lower temperatures of $240{ }^{\circ} \mathrm{C} .{ }^{17,18}$ The resulting $\mathrm{Cu}_{2} \mathrm{ZnSnS}_{4}$ nanoparticles also had a kesterite structure and a diameter of $18 \pm 4 \mathrm{~nm}$. Thin layers of these nanoparticles were prepared by a drop cast method. The structure of the nanoparticles was verified by $\mathrm{X}$-ray diffraction measurements.

XANES measurements were performed at the x-ray absorption spectroscopy beamline (BL-8) of the Siam Photon Source (electron energy of $1.2 \mathrm{GeV}$, beam current 80-120 mA), Synchrotron Light Research Institute in Thailand. A double crystal monochromator InSb (111) was used to adjust the energy of the synchrotron $\mathrm{x}$-ray beam with $0.20 \mathrm{eV}$ energy steps. For measurements in the fluorescent mode, the signal was detected with a 13-component Ge detector. In transmission mode of measurements, we use ion chambers. X-ray intensities were recorded using two $10 \mathrm{~cm}$ long ion-chambers placed before and after the sample to record incoming and transmission X-ray intensities. Both ionchambers were filled with $63 \mathrm{kPa} \mathrm{N} \mathrm{N}_{2}$ gas. The normalization of the data was performed using the package ATHENA. ${ }^{19}$

Samples for transmission measurements consisted of a homogeneous layer of dried nanoparticle powder in between two sheets of Kapton ${ }^{\circledR}$ tape. The thickness of the powder layers was optimized to give an appropriate edge jump.

XANES spectra were simulated using the FEFF 8.2 $\operatorname{code}^{20}$ based on ab-initio multiple scattering calculations for structures with varied occupations of lattice sites. The simulation was based on Hedin-Lundqvist self-energy without consideration of an edge shift and no exponential broadening. An amplitude reduction factor $S_{0}^{2}=0.5$ and a maximum k-value of 5 was used for the simulation. Full multiple scattering was considered within a radius of $6 \AA$ surrounding the central sulfur atom, considering thus scattering in the first 5 shells.

A XANES spectrum was measured in the transmission mode on $\mathrm{Cu}_{2} \mathrm{ZnSnS}_{4}$ nanoparticles synthesized by a reaction of $\mathrm{Cu}_{2} \mathrm{SnS}_{3}$ and $\mathrm{ZnS}$ nanoparticles (Figure 2). As a remark, measurements in the fluorescence mode gave the same spectra with a lower signal to noise ratio for the same accumulation times.

For comparison, XANES on $\mathrm{Cu}_{2} \mathrm{SnS}_{3}$ precursor nanoparticles was measured. In stannite $\mathrm{Cu}_{2} \mathrm{SnS}_{3}$, the $4 \mathrm{~d}$ and $2 \mathrm{~b}$

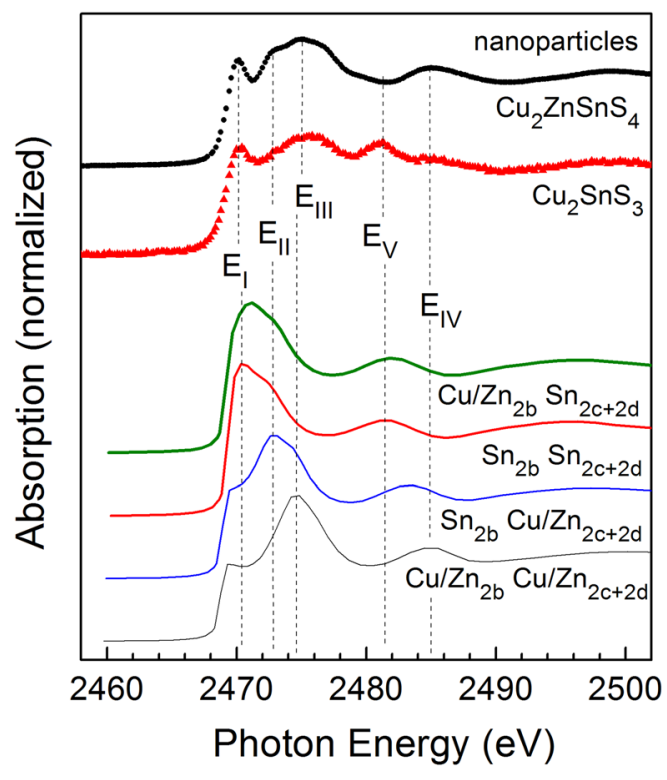

FIG. 2. Measured (symbols) and simulated (lines) normalized XANES spectra at the $\mathrm{S} \mathrm{K}$-edge of $\mathrm{Cu}_{2} \mathrm{ZnSnS}_{4}$ (black circles) and $\mathrm{Cu}_{2} \mathrm{SnS}_{3}$ (red triangles) nanoparticles and of kesterite type lattice structures with varied positions of $\mathrm{Sn}$ atoms: $\mathrm{Cu}$ and $\mathrm{Zn}$ replace $\mathrm{Sn}$ at $2 \mathrm{~b}$ site and $\mathrm{Cu}$ and $\mathrm{Zn}$ at $2 \mathrm{c}$ and $2 \mathrm{~d}$ sites (thinnest black line); $\mathrm{Sn}$ at $2 \mathrm{~b}$ site and $\mathrm{Cu}$ and $\mathrm{Zn}$ at $2 \mathrm{c}$ and $2 \mathrm{~d}$ sites (thin blue line); $\mathrm{Sn}$ at $2 \mathrm{~b}$ site and $\mathrm{Sn}$ replace $\mathrm{Cu}$ and $\mathrm{Zn}$ at $2 \mathrm{c}$ and $2 \mathrm{~d}$ sites (thick red line); $\mathrm{Cu}$ and $\mathrm{Zn}$ replace $\mathrm{Sn}$ at $2 \mathrm{~b}$ site and $\mathrm{Sn}$ replace $\mathrm{Cu}$ and $\mathrm{Zn}$ at $2 \mathrm{c}$ and $2 \mathrm{~d}$ sites (thickest green line). The baselines of the spectra are shifted.

positions are partially occupied by $\mathrm{Cu}$ and $\mathrm{Sn}^{21}$ The $4 \mathrm{~d}$ position in stannite is equal to the $2 \mathrm{c}$ and $2 \mathrm{~d}$ position in kesterite which is occupied by $\mathrm{Cu}$ and $\mathrm{Zn}$, respectively (see Figure 1). The $2 \mathrm{~b}$ position in kesterite is occupied by Sn. Therefore, upon reaction of $\mathrm{Cu}_{2} \mathrm{SnS}_{3}$ with $\mathrm{ZnS}$, the Sn should move out of the $4 \mathrm{~d}$ position into the $2 \mathrm{~b}$ position, whereas the $\mathrm{Cu}$ should leave the $2 \mathrm{~b}$ site and move into the $2 \mathrm{c}$ position.

The XANES spectra of $\mathrm{Cu}_{2} \mathrm{ZnSnS}_{4}$ and $\mathrm{Cu}_{2} \mathrm{SnS}_{3}$ nanoparticles not only show some similar features but also show some clear differences. Four main peaks were found in the XANES spectrum of $\mathrm{Cu}_{2} \mathrm{ZnSnS}_{4}$ nanoparticles at $2470 \mathrm{eV}$ $\left(\mathrm{E}_{\mathrm{I}}\right), 2473 \mathrm{eV}\left(\mathrm{E}_{\mathrm{II}}\right), 2475 \mathrm{eV}\left(\mathrm{E}_{\mathrm{III}}\right)$, and $2485 \mathrm{eV}\left(\mathrm{E}_{\mathrm{IV}}\right) . \mathrm{A}$ peak at $2481 \mathrm{eV}\left(\mathrm{E}_{\mathrm{V}}\right)$ was found in the XANES spectrum of $\mathrm{Cu}_{2} \mathrm{SnS}_{3}$ in addition to the $\mathrm{E}_{\mathrm{I}-\mathrm{IV}}$ peaks found in XANES spectra of $\mathrm{Cu}_{2} \mathrm{ZnSnS}_{4}$ nanoparticles. Note that the shoulder at $\mathrm{E}_{\mathrm{II}}$ was missing in the spectrum of $\mathrm{Cu}_{2} \mathrm{SnS}_{3}$.

A classification of certain peak positions in XANES spectra with respect to the occupation of lattice sites is desired for thin film analysis. From the simulation results, it has been observed that the occupations of $\mathrm{Cu}$ and $\mathrm{Zn}$ are hardly distinguished in the XANES analysis, partly due to the fact that the atomic numbers of $\mathrm{Cu}$ and $\mathrm{Zn}$ are very close and $\mathrm{Cu}^{+}$and $\mathrm{Zn}^{2+}$ having similar symmetry and electron configuration in the input crystal structure. A similar trend has been observed for indium oxynitride alloys by T-Thienprasert et al. ${ }^{22}$ This behavior is indicated as $\mathrm{Cu} / \mathrm{Zn}$ for any site occupied with $\mathrm{Cu}$ or $\mathrm{Zn}$. Furthermore, the $2 \mathrm{c}$ and $2 \mathrm{~d}$ positions are very similar and do not cause differences in the simulated XANES spectra.

In Figure 2, the results of the simulations with different occupations of the critical $2 b$ and $2 c+2 d$ sites are plotted. The nomenclatures $\mathrm{Cu} / \mathrm{Zn}_{2 \mathrm{~b}} \mathrm{Cu} / \mathrm{Zn}_{2 \mathrm{c}+2 \mathrm{~d}}, \mathrm{Sn}_{2 \mathrm{~b}} \mathrm{Cu} / \mathrm{Zn}_{2 \mathrm{c}+2 \mathrm{~d}}$, $\mathrm{Sn}_{2 \mathrm{~b}} \mathrm{Sn}_{2 \mathrm{c}+2 \mathrm{~d}}$, and $\mathrm{Cu} / \mathrm{Zn}_{2 \mathrm{~b}} \mathrm{Sn}_{2 \mathrm{c}+2 \mathrm{~d}}$ are related to the atoms 
occupying the indicated lattice sites. The peaks at $\mathrm{E}_{\mathrm{III}}$ and $\mathrm{E}_{\mathrm{IV}}$ correlate very well with the peaks at 2475 and $2485 \mathrm{eV}$ of the simulated spectrum with $\mathrm{Cu} / \mathrm{Zn}_{2 \mathrm{~b}} \mathrm{Cu} / \mathrm{Zn}_{2 \mathrm{c}+2 \mathrm{~d}}$ occupation.

The peak at $\mathrm{E}_{\mathrm{II}}$ appeared only in the simulated XANES spectrum with $\mathrm{Sn}_{2 \mathrm{~b}} \mathrm{Cu} / \mathrm{Zn}_{2 \mathrm{c}+2 \mathrm{~d}}$ occupation which corresponds to the stoichiometric kesterite structure. The $\mathrm{E}_{\mathrm{V}}$ peak at $2481 \mathrm{eV}$ appeared in the simulated XANES spectra with $\mathrm{Sn}_{2 \mathrm{~b}} \mathrm{Sn}_{2 \mathrm{c}+2 \mathrm{~d}}$ and $\mathrm{Cu} / \mathrm{Zn}_{2 \mathrm{~b}} \mathrm{Sn}_{2 \mathrm{c}+2 \mathrm{~d}}$ occupations. It can be concluded that the $\mathrm{E}_{\mathrm{V}}$ peak is related to the occupation of $2 c+2 d$ sites by $\mathrm{Sn}$ atoms.

However, the $\mathrm{E}_{\mathrm{I}}$ peak is difficult to be classified by the XANES simulations. The first peak of the simulations with $\mathrm{Sn}$ on the $2 c+2 d$ position fits energetically with $E_{\mathrm{I}}$. However, the peak in the simulation is much broader and $\mathrm{E}_{\mathrm{I}}$ does not correlate with $\mathrm{E}_{\mathrm{V}}$, as $\mathrm{E}_{\mathrm{I}}$ is present in both nanoparticle samples and $\mathrm{E}_{\mathrm{V}}$ only in $\mathrm{Cu}_{2} \mathrm{SnS}_{3}$. The simulation where $\mathrm{Cu} / \mathrm{Zn}$ occupied the native $\mathrm{Sn}$ site (2b) also shows a small peak in the range of $2470 \mathrm{eV}$. Therefore, $E_{I}$ was correlated with $\mathrm{Cu} / \mathrm{Zn}$ on the $2 \mathrm{~b}$ site. The slight differences between measurements and simulation can be explained by slight local disturbances in the lattice, which were not considered in XANES simulations.

The disappearance of the $\mathrm{E}_{\mathrm{V}}$ peak present in the XANES spectrum of $\mathrm{Cu}_{2} \mathrm{SnS}_{3}$ and the appearance of the $\mathrm{E}_{\mathrm{II}}$ peak after reaction with $\mathrm{ZnS}$ is a result of the shift of $\mathrm{Sn}$ atoms from the $2 \mathrm{c}+2 \mathrm{~d}$ sites into its native position in kesterites, i.e. the $2 b$ site. $E_{I}$ however also indicates a certain amount of $\mathrm{Cu} / \mathrm{Zn}$ in the $2 \mathrm{~b}$ position. Therefore, anti-site defects in $\mathrm{Cu}_{2} \mathrm{ZnSnS}_{4}$ were present and the $\mathrm{Cu}_{2} \mathrm{ZnSnS}_{4}$ nanoparticles were $\mathrm{Sn}$ deficient.

Apart from anti-site defects also vacancies can lead to electron and hole traps in kesterite structures. ${ }^{11}$ To see the influences of vacancies on near edge X-ray absorption, simulations with $2 \mathrm{a}, 2 \mathrm{~b}$, and $2 \mathrm{c}+2 \mathrm{~d}$ vacancies were performed and have been shown in Figure 3. The vacancies generally cause a shift of the peaks to higher energies and a peak around $2470 \mathrm{eV}$ evolves. The strongest shift is caused by vacancies on the $2 \mathrm{~b}$ site, whereas the most pronounced peak at $2470 \mathrm{eV}$ is caused by the $2 \mathrm{c}+2 \mathrm{~d}$ vacancies. Note that the simulation with the $S n$, the $2 b$ vacancy is very similar to the

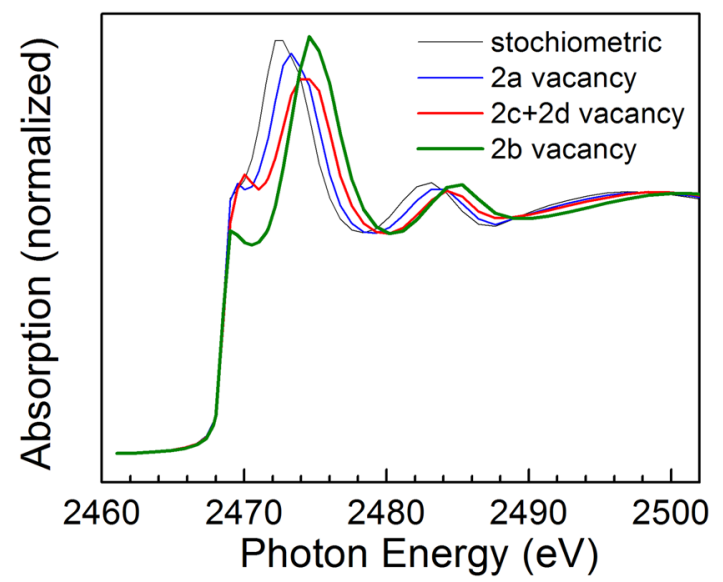

FIG. 3. Simulated XANES spectra at the $\mathrm{S}$ K-edge of $\mathrm{Cu}_{2} \mathrm{ZnSnS}_{4}$ with a stoichiometric structure (thinnest black line) and vacancies at the $2 \mathrm{a}$ (thin blue line), the $2 c+2 d$ (thick red line), and the $2 b$ (thickest green line) site. simulation with $\mathrm{Cu} / \mathrm{Zn}_{2 \mathrm{~b}} \mathrm{Cu} / \mathrm{Zn}_{2 \mathrm{c}+2 \mathrm{~d}}$. Therefore, it cannot be distinguished between a $\mathrm{Cu} / \mathrm{Zn}$ anti-site defect and a vacancy on the $2 \mathrm{~b}$ position.

The analysis of the peak positions in XANES spectra can be used to monitor changes in the occupation of lattice sites during the phase transformation of precursor nanoparticles into kesterites and/or during further processing such as annealing, sulfurization or selenization. As an example, Figure 4 shows XANES spectra of thin films of kesterite nanoparticles deposited by drop casting on substrates (Figure 4(a)) and post-treated at $200^{\circ} \mathrm{C}$ in $\mathrm{N}_{2}$ atmosphere (Figure 4(b)) or at $500^{\circ} \mathrm{C}$ in $\mathrm{H}_{2} \mathrm{~S} / \mathrm{Ar}$ atmosphere (Figure 4(c)). Additionally, the relevant simulations were plotted with the measured XANES spectra. The $\mathrm{Cu}_{2} \mathrm{ZnSnS}_{4}$ nanoparticles used for these experiments were prepared by a one pot technique. The XANES spectra of the $\mathrm{Cu}_{2} \mathrm{ZnSnS}_{4}$ nanoparticle thin films were measured in the fluorescence mode as measurement in the transmission mode was not possible due to absorption by the substrate.

The spectrum of the as deposited $\mathrm{Cu}_{2} \mathrm{ZnSnS}_{4}$ nanoparticles showed some differences to the $\mathrm{Cu}_{2} \mathrm{ZnSnS}_{4}$ nanoparticle spectrum in Figure 2. For the nanoparticles from the one pot synthesis (Figure 4), the peak at $2470 \mathrm{eV}\left(\mathrm{E}_{\mathrm{I}}\right)$ was less pronounced and a peak at $2481 \mathrm{eV}\left(\mathrm{E}_{\mathrm{V}}\right)$ was found in contrast to the nanoparticles from colloidal synthesis (Figure 2). The reduced intensity of the peak at $2470 \mathrm{eV}$ indicate less $\mathrm{Cu} / \mathrm{Zn}$ in the native Sn site (2b), or vacancies and the peak at

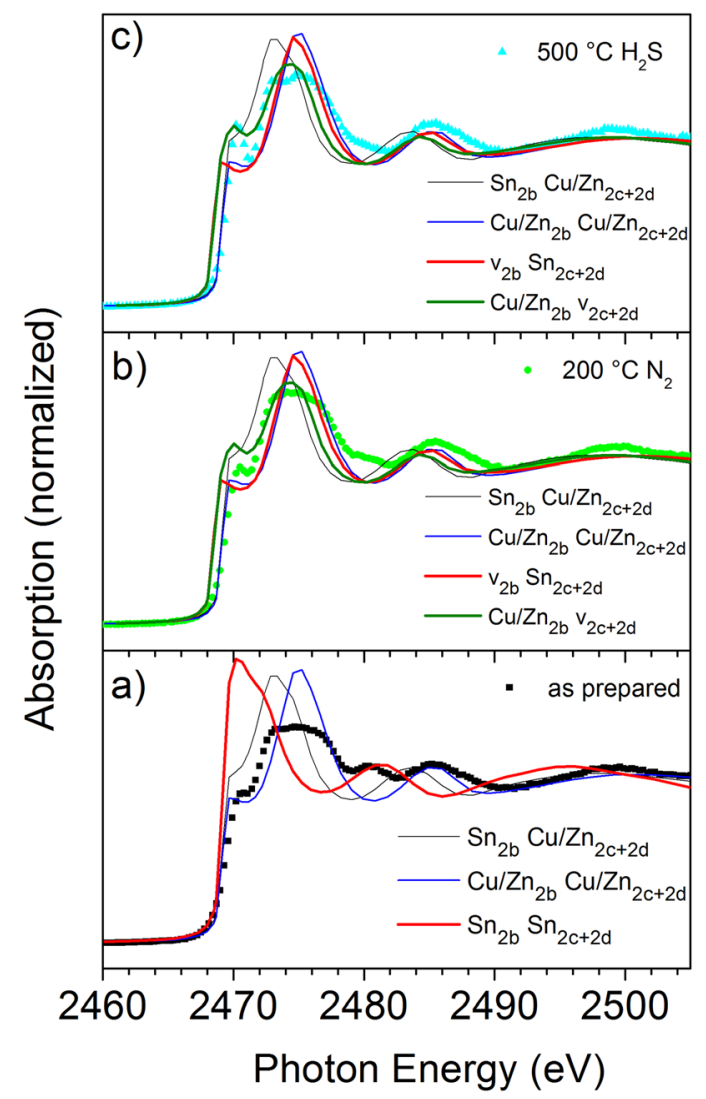

FIG. 4. Measured and simulated normalized XANES spectra at the S Kedge of (a) as prepared (black squares) and (b) annealed in $\mathrm{N}_{2}$ atmosphere at $200^{\circ} \mathrm{C}$ (green circles) and (c) in $\mathrm{H}_{2} \mathrm{~S} / \mathrm{Ar}$ atmosphere (blue triangles) $\mathrm{Cu}_{2} \mathrm{ZnSnS}_{4}$ nanoparticle thin films. The measured XANES spectra are compared with different simulations. 
$2481 \mathrm{eV}$ points towards some $\mathrm{Sn}$ in the $2 \mathrm{c}+2 \mathrm{~d}$ site, which is the native $\mathrm{Cu}$ and $\mathrm{Zn}$ site.

Heating at $200^{\circ} \mathrm{C}$ under nitrogen atmosphere reduced the intensity of the peak at $2481 \mathrm{eV}$ and slightly increased the intensity of the peak at $2470 \mathrm{eV}$. Therefore, heating at $200^{\circ} \mathrm{C}$ mainly reduced the occupation of the $2 \mathrm{c}+2 \mathrm{~d}$ site with Sn atoms. The slight increase of the peak at $2470 \mathrm{eV}$ can be either explained by an increase of $\mathrm{Cu} / \mathrm{Zn}$ in the $2 \mathrm{~b}$ site or a development of vacancies.

Upon heating at $500{ }^{\circ} \mathrm{C}$ in $\mathrm{H}_{2} \mathrm{~S}$ atmosphere, the intensity of the peak at $2481 \mathrm{eV}$ decreased further while the intensity of the peak at $2470 \mathrm{eV}$ increased strongly. Therefore, the occupation of the $2 c+2 d$ site with $\mathrm{Sn}$ atoms was further decreased, but the major change was an increase of $\mathrm{Cu} / \mathrm{Zn}$ in the $2 \mathrm{~b}$ site or a development of vacancies.

Generally, a loss of $\mathrm{Sn}$ in $\mathrm{Cu}_{2} \mathrm{ZnSnS}_{4}$ nanoparticle films, in both the $2 b$ and the $2 c+2 d$ sites, took place upon heating. As the amount of $\mathrm{Cu}$ and $\mathrm{Zn}$ in the sample is not increased, the loss of Sn leaves vacancies. Whether the vacancies are only present in one of the lattice sites or in both the $2 \mathrm{~b}$ and the $2 \mathrm{c}+2 \mathrm{~d}$ site, cannot be verified by XANES simulation.

By comparison of XANES measurements and simulations at the $\mathrm{S} \mathrm{K}$-edge, it has been shown that XANES is sensitive to $\mathrm{Sn}_{\mathrm{Cu} / \mathrm{Zn}}$ and $\mathrm{Cu} / \mathrm{Zn}_{\mathrm{Sn}}$ anti-site defects and vacancies. The occupation of lattice sites is dependent on both the synthesis method used and the treatment of nanoparticles.

XANES measurements and simulations point towards $\mathrm{Cu} / \mathrm{Zn}$ anti-site defects on the intrinsic $\mathrm{Sn}(2 \mathrm{~b})$ position, or vacancies in colloidal synthesized $\mathrm{Cu}_{2} \mathrm{ZnSnS}_{4}$ nanoparticles. According to Walsh et al. ${ }^{11}$ the formation energies of most acceptor states are lower than the formation energies of donor states, resulting in a p-type material. This is also in accordance with surface photovoltage measurements of $\mathrm{Cu}_{2} \mathrm{ZnSn}\left(\mathrm{S}_{\mathrm{x}} \mathrm{Se}_{1-\mathrm{x}}\right)_{4}$ layers. ${ }^{23}$ In p-type $\mathrm{Cu}_{2} \mathrm{ZnSnS}_{4}$, the $\mathrm{Sn}$ vacancy has a much higher formation energy $(\sim 3 \mathrm{eV})$ than the $\mathrm{Cu} / \mathrm{Zn}$ anti-site defect and the $\mathrm{Cu} / \mathrm{Zn}$ vacancy, which have very similar formation energies $(\sim 1 \mathrm{eV})$. Therefore, the formation of $\mathrm{Sn}$ vacancies creating deep defects is quite unlikely. The $\mathrm{Cu} / \mathrm{Zn}$ vacancy and the $\mathrm{Zn}$ anti-site defect create only shallow acceptor states. However, the $\mathrm{Cu}$ anti-site defect also creates a deep defect, which would limit the performance of solar cells. ${ }^{11}$

The $\mathrm{Sn}_{\mathrm{Cu} / \mathrm{Zn}}$ anti-site defects observed for $\mathrm{Cu}_{2} \mathrm{ZnSnS}_{4}$ nanoparticles from the one-pot synthesis create deep defects $\left(\mathrm{Sn}_{\mathrm{Cu}}\right)$ or donor states $\left(\mathrm{Sn}_{\mathrm{Zn}}\right)$, which would be both unfavorable for p-type $\mathrm{Cu}_{2} \mathrm{ZnSnS}_{4}$ solar cells. However, these defects are easily reduced by annealing with $200^{\circ} \mathrm{C}$ under nitrogen atmosphere. The strong increase of the peak at $2470 \mathrm{eV}$ during heating at $500{ }^{\circ} \mathrm{C}$ under $\mathrm{H}_{2} \mathrm{~S}$ points towards a further loss of $\mathrm{Sn}$ at its native site. As the formation of an Sn vacancy is energetically unfavorable, ${ }^{11}$ the loss of $\mathrm{Sn}$ is in all likelihood compensated by $\mathrm{Zn}$ and $\mathrm{Cu}$ on the native $\mathrm{Sn}$ site, resulting in $\mathrm{Cu}$ and $\mathrm{Zn}$ vacancies.
The measurements show that composition of the $\mathrm{Cu}_{2} \mathrm{ZnSnS}_{4}$ layer and the defect positions strongly depend on the treatments of the $\mathrm{Cu}_{2} \mathrm{ZnSnS}_{4}$ nanoparticle thin films. The monitoring of changes of the occupation of lattice sites due to annealing during the preparation of solar cells is an important issue. XANES can be used as a method for technology development by monitoring changes in the defect positions and correlating them to solar cell performances. Further experiments to correlate defects with solar cell performances are required.

The work was supported by the BMBF (Grant No. 03SF0363B). Muangjai Unruan, Atipong Bootchanont, Sukit Limpijumnong, and Wantana Klysuban are acknowledged for support with the XAS measurements and discussions. We are also grateful to the reviewer for suggesting a consideration of vacancies.

${ }^{1}$ K. Ito and T. Nakazawa, Jpn. J. Appl. Phys., Part 1 27, 2094 (1988).

${ }^{2}$ H. Katagiri, K. Jimbo, S. Yamada, T. Kamimura, W. Shwe Maw, T. Fukano, T. Ito, and T. Motohiro, Appl. Phys. Express 1, 041201 (2008).

${ }^{3}$ D. Aaron, R. Barkhouse, O. Gunawan, T. Gokmen, T. K. Todorov, and D. B. Mitzi, Prog. Photovoltaics 20, 6 (2012).

${ }^{4}$ S. Bag, O. Gunawan, T. Gokmen, Y. Zhu, T. K. Todorov, and D. B. Mitzi, Energy Environ. Sci. 5, 7060 (2012).

${ }^{5}$ T. K. Todorov, J. Tang, S. Bag, O. Gunawan, T. Gokmen, Y. Zhu, and D. B. Mitzi, Adv. Energy Mater. 3, 34 (2013).

${ }^{6}$ Q. Guo, G. M. Ford, W. C. Yang, B. C. Walker, E. A. Stach, H. W. Hillhouse, and R. Agrawal, J. Am. Chem. Soc. 132, 17384 (2010).

${ }^{7}$ H. Katagiri, Thin Solid Film 480, 426 (2005).

${ }^{8}$ H. Katagiri, K. Jimbo, W. S. Maw, K. Oishi, M. Yamazaki, H. Ariki, and A. Takeuchi, Thin Solid Film 517, 2455 (2009).

${ }^{9}$ K. Jimbo, R. Kimura, T. Kamimure, S. Yamada, W. S. Maw, H. Ariki, K. Oishi, and H. Katagiri, Thin Solid Films 515, 5997 (2007).

${ }^{10}$ K. Biswas, S. Lany, and A. Zunger, Appl. Phys. Lett. 96, 201902 (2010).

${ }^{11}$ A. Walsh, S. Chen, S.-H. Wei, and X.-G. Gong, Adv. Energy Mater. 2, 400 (2012).

${ }^{12}$ G. P. Bernardini, D. Borrini, A. Caneschi, F. Di Benedetto, D. Gatteschi, S. Ristori, and M. Romanelli, Phys. Chem. Miner. 27, 453 (2000).

${ }^{13}$ S. Schorr, H.-J. Hoebler, and M. Tovar, Eur. J. Miner. 19, 65 (2007).

${ }^{14}$ T. Washio, H. Nozaki, T. Fukano, T. Motohiro, K. Jimbo, and H. Katagiri, J. Appl. Phys. 110, 074511 (2011).

${ }^{15}$ S. R. Hall, J. T. Szymanski, and J. M. Stewart, Can. Miner. 16, 131 (1978).

${ }^{16}$ J. Just, D. Lützenkirchen-Hecht, R. Frahm, S. Schorr, and T. Unold, Appl. Phys. Lett. 99, 262105 (2011).

${ }^{17}$ C. Steinhagen, M. G. Pathani, V. Akhavan, B. Goodfellow, B. Koo, and B. A. Korgel, J. Am. Chem. Soc. 131, 12554 (2009).

${ }^{18}$ X. Z. Lin, J. Kavalakkatt, M. Lux-Steiner, and A. Ennaoui, in Proceedings of 26th European Photovoltaics Solar Energy Conference, Hamburg, Germany, 5-8 September (2011), pp. 2896-2899.

${ }^{19}$ J. J. Rehr, J. Mustre de Leon, S. I. Zabinsky, and R. C. Albers, J. Am. Chem. Soc. 113, 5135 (1991).

${ }^{20}$ A. L. Ankudinov, B. Ravel, J. J. Rehr, and S. D. Conradson, Phys. Rev. B $\mathbf{5 8 ,} 7565$ (1998).

${ }^{21}$ X. Chen, H. Wada, A. Sato, and M. Mieno, J. Solid State Chem. 139, 144 (1998).

${ }^{22}$ J. T-Thienprasert, J. Nukeaw, A. Sungthong, S. Porntheeraphat, S. Singkarat, D. Onkaw, S. Rujirawat, and S. Limpijumnong, Appl. Phys. Lett. 93, 051903 (2008).

${ }^{23}$ X. Z. Lin, Th. Dittrich, S. Fengler, M. Ch. Lux-Steiner, and A. Ennaoui, Appl. Phys. Lett. 102, 143903 (2013). 